chemicals need to be studiod, however, and the distribution of the chemicals in the soil, their broakdown and possible phytotoxic effects are boing investigated in the laboratory.

Tho problem of rosistance to acaricides shown by the glasshouse rod spider mite (Tetranychus urticae Koch), which is assuming serious proportions in the Lea Valley on cucumbers, is being tackled as a cooperativo project by the Crop Protection Department, under Mr. W. H. Read, and the Entomology Department, undor Dr. N. W. Hussey. This work involves tho testing of Lea Valley strains of the mite for crossresistance to other $\varepsilon_{0}$ caricides to assess the practicability of incroasing the range of materials in use. This is to bo followed by large-scale trials later this year to investigate control of the pest by physical and biological agencies to which it is unlikely to develop rosistance.

\title{
SCIENCE TEACHING IN SECONDARY MODERN SCHOOLS
}

$S^{1}$ ERIOUS deficiencies in the provision of science teachers, laboratories and science equipment in many secondary modern schools are revealed in the results of a survey carried out by the Science Masters' Association. Three-quarters of the nation's children attend secondary modern schools, yet in many of them serious shortages are revoalcd. Many schools returnod the questionnaire stating that they provided no teaching in science, 73 taught no seionce because there were no teaching facilities, 33 becauso there were no teachers available who were capable of teaching science.

The material on the survoy was collected from more than 1,500 questionnaires. The return compared with a total of about 3,700 schools of this typo existing in 1958; the investigation was conducted throughout by the Secondary Modern Schools' Com. mittee of the Science Masters' Association.

The Committee believes that there should be one laboratory for each 300 pupils in the school, two for schools of 301-600 pupils, and three for those of more than 600 . The survey states that on investigating the conditions under which seience was being taught in secondary modern schools, 47 per cent are obliged to teach all or part of their science under unsatis. factory conditions.

The investigation revealed that only one science teacher in six in a secondary modern school is a graduate, while about one in six has "no pretensions at all to science qualifications". Only 34 per cent of the schools considered that they were adequately staffed for teaching science. Special account is taken in the survey of head teachers' opinions on the most important needs to improve seience teaching. Their orders of priority are more science teachers, more laboratory accommodation, and more equipment.

The statistical roturn suggests that, in 65 per cent of the schools concermed in the survey, more science staff are needed. The booklet comments : "It follows that in the country as a whole no fewor than 2,500 schools need science teachers and in some cases more than one teacher will be required".

Copies of the booklet are available, price $1 s$, from Mr. D. M. Chillingworth, The Village College, Swavesey, Cambridgeshire.

\section{SCIENTIFIC RESEARCH IN EAST AFRICA}

\begin{abstract}
JUST over half the annual report of the East Africa High Commission for 1959 deals with the East African Research and Scientific Services, on which some $£ 706,466$ was expended, with a further $£ 212,962$ on the Desert Locust Survey, $£ 270,812$ on the Meteorological Department and $£ 470,645$ on the Directorate of Civil Aviation, out of a total recurrent expenditure in 1958-59 of $£ 3,907,933$, towards which $£ 567,863$ was received from the United Kingdom Government in Colonial Development and Welfare or direct Exchequer grants*. Some account of the work of these regional organizations, for example the East African Agriculture and Forestry Research Organization, the Veterinary Research Organization, the Fishery Research Organization and the Institute for Medical Research, was included in tho roports published under the title "Colonial Research 195859 ", but no reference was made in that report to the curtailment of rescarch programmes through tho reduction of scientific staff at some of the High Commission's organizations in consequence of territorial financial cuts. The East African Agriculturo and Fisheries Organization report, for example, refers to the reduction of the establishment of research

- East Africa High Commission. Annual Report, 1959. Pp. iv + 100. (Nairobi: Government Printer, 1960.) Sh. 5.
\end{abstract}

officers from 28 to 23 and of scientific assistants from 20 to 14, chiefly in the Divisions concerned with soil fertility, soil chemistry and soil classification, with the result that the Organization is not always able to co-operate effectively with the Torritorial Departments. The Trypanosomiasis Research Organization also refers to reduction in staff, and the Meteorological Dopartment has found the difficulty of recruiting staff from Britain to constitute a formidable obstacle in its programme of expansion. On the other hand, help is being received from the Rockefeller Foundation for agricultural research in East Africa, and the Nuffield Foundation is financing further research on the physiology of drought resistanco in crops, and on the improvement of the nitrogen status of tropical soils by suitable uso of indigonous tropical legumes.

The work of the Agriculture and Forestry Research Organization has included work on the increase of crop-yields by reducing the damage done by pests and diseases, such as the study of 'stem pitting' of arabica coffec, a survoy of the nomatodes of the principal East African crops, the development of a strain of maize resistant to the virus disease known as 'streak', and also work on the effect of drought on the growth of plants and the water requirements of 